\title{
GOING CONCERN AUDIT DETERMINATION IN INDONESIAN AGRICULTURAL SECTOR
}

\author{
Mohamad Zulman Hakim \\ University of Muhammadiyah Tangerang \\ mohamadzulmanhakim@ymail.com
}

\begin{abstract}
The purpose of this research is to know the influence of debt to equity ratio (DER), company size (SIZE), current ratio (CR) and reputation of Public Accounting Firm (KAP) to going concern audit opinion (GCAO) in agricultural sector companies listed in Indonesia Stock Exchange period 2012-2016. The study population includes all agricultural sector companies listed in Indonesia Stock Exchange period 2012-2016. The sampling technique used purposive sampling technique with sample of 16 companies and 80 observations. Data analysis method used is panel data logistic regression analysis with using program EViews (Econometric Views) version 9.0. The results showed that the debt to equity ratio (DER) has a positive effect to going concern audit opinion (GCAO), the size of the company (SIZE) has a negative effect to going concern audit opinion (GCAO), current ratio $(C R)$ and reputation of Public Accounting Firm (KAP) doesn't affect the going concern audit opinion $(G C A O)$.
\end{abstract}

Keywords: Going Concern Audit Opinion (GCAO), Debt to Equity Ratio (DER), Company Size (SIZE), Current Ratio (CR) and Reputation of Public Accounting Firm (KAP)

\begin{abstract}
Abstrak
Tujuan penelitian ini adalah untuk mengetahui pengaruh debt to equity ratio (DER), ukuran perusahaan (SIZE), current ratio (CR) dan reputasi Kantor Akuntan Publik (KAP) terhadap going concern audit opinion (GCAO) di sektor pertanian. perusahaan yang terdaftar di Bursa Efek Indonesia periode 2012-2016. Populasi penelitian mencakup semua perusahaan sektor pertanian yang terdaftar di Bursa Efek Indonesia periode 2012-2016. Teknik pengambilan sampel menggunakan teknik purposive sampling dengan sampel 16 perusahaan dan 80 observasi. Metode analisis data yang digunakan adalah analisis regresi logistik data panel dengan menggunakan program EViews (Econometric Views) versi 9.0. Hasil penelitian menunjukkan bahwa debt to equity ratio (DER) memiliki pengaruh positif terhadap going concern audit opinion (GCAO), ukuran perusahaan (SIZE) memiliki pengaruh negatif terhadap going concern audit opinion (GCAO), current ratio (CR) ) dan reputasi Kantor Akuntan Publik (KAP) tidak mempengaruhi opini audit going concern (GCAO).
\end{abstract}


Kata kunci: Going Concern Audit Opinion (GCAO), Debt to Equity Ratio (DER), Ukuran Perusahaan (SIZE), Current Ratio (CR) dan Reputasi Kantor Akuntan Publik (KAP)

\section{INTRODUCTION}

The role of the auditor is necessary to prevent the publication of misleading financial statements, so that by using audited financial statements the users of the financial statements can make informed decisions. The auditor is also responsible for assessing whether there are doubts to the company in maintaining its viability within a period of not more than one year from the date of the audit report (SPAP Section 341, 2011). The going concern assumption is one of the assumptions used in preparing financial statements. This assumption requires that economic entities operationally and financially have the ability to maintain their business continuity (Purba, 2016). Agricultural sector companies 2012-2016 period listed on the BEI and get going concern audit opinion, namely: PT. Central Proteina Prima, Tbk, PT. Dharma Samudra Fishing Industries, Tbk, PT. Inti Agri Resaurces, Tbk.

\section{LITERATURE REVIEW}

Agency Theory a contractual model between two or more persons, in which one party is called the agent and the other is called the principal. Principal delegates responsibility to the agent, it can also be said that the principal provides a mandate to the agent to perform certain tasks in accordance with the contract of work on mutual agreement (Tandiontong, 2016).

Expressing Saifudin and Trisnawati (2015) there are three assumptions of human nature related to agency theory that is Humans are generally self-centered (selft-interest), Humans have limited thinking about future perceptions (bounded rationality), People always avoid risk (risk averse).

Signal theory describes how a company in giving a signal to users of financial statements, namely in the form of information disclosed management. Information published by management will provide a signal to investors and creditors in making decisions. When information has been disclosed to the public, market participants will interpret and analyze the information as a good signal or a bad signal. Disclosure of such information is one way to reduce the information asymmetry that occurs between principal and agent (Elmawati and yuyetta, 2014).

Auditing According to the Indonesian Institute of Certified Public Accountants auditing is an objective examination of the financial statements of a company or organization in order to determine whether the financial statements (Junaidi and Nurdiono, 2016). 
Going Concern Audit Opinion PSA 30 paragraph 6 states that the auditor may identify certain conditions or events which, when considered as a whole, indicate a great doubt about the entity's ability to maintain its viability within a reasonable period of time. An example of information that can be used as a guide as follows:

a. Negatif Trend. For example operating losses, lack of working capital, and important bad financial ratios.

b. Another difficult indication. For example, unable to pay (default) a loan, delinquent dividend payments, debt restructuring, and a refusal by the supplier to apply for ordinary credit, debt restructuring, the need to find a source or method of new funding or the sale of most assets.

c. Things related to internal issues. For example, work strikes or other labor difficulties, great reliance on certain project successes, and long term noneconomic commitments.

d. Matters relating to external issues. For example loss of franchise, or loss due to flood or earthquake disaster 6.

Debt to Equity Ratio (DER) is the ratio used to assess debt with equity. This ratio is sought by comparing the entire debt, including current debt with all equities. This ratio is useful to know the amount of funds provided loans (creditors) with the owner of the company. In other words, this ratio serves to know each rupiah of its own capital is used for debt guarantees (cashmere, 2015).

The size of a company is a scale that can be classified by small companies in various ways including total assets, log size, stock market value and so on. Total assets are selected as a proxy for firm size considering that asset values are relatively more stable than market capitalized and sales (Elmawati and Yuyetta, 2014).

Current Ratio is a ratio to measure the company's ability to pay short-term liabilities or debts that are due soon. The current ratio can also be said as a form to measure the safety level (margin of safety) of a company (Kashmir, 2015).

KAP in Indonesia affiliated with The Big Four are:

a. Ernst and Young in 2010 were affiliated with KAP Purwantono, Suherman and Surja. Local KAP affiliated with Ernest and Young previously ie in 2006 is KAP Purwantono, Sarwoko, and Sandjaja.

b. Deloitte touche Tohmatsu is affiliated with KAP Osman Bing Satrio.

c. Klyveld Peat Marwick Geordeler (KPMG) International is affiliated with KAP Sidharta and Widjaja.

d. Price Waterhouse Coopers in 2009 was affiliated with KAP Tanudireja, Wibisana and Partners. Prior to affiliating with KAP Tanudireja, Wibisana and Partners, Price Waterhouse Coopers affiliated with the local KAP, KAP Haryanto Sahari in 2005.

\subsection{Research Hypothesis}

a. Debt to Equity (DER) represents the ratio of total debt held by companies with their own capital (Harjito and Martono, 2013). Debt to Equity Ratio (DER) is the ratio used to assess debt with equity. The higher ratio of debt to 
equity ratio of a company, the higher the possibility of the company getting going concern audit opinion from the auditor (Izzati and Sularto, 2014). H1: Debt to Equity (DER) has a positive effect on going concern audit opinion.

b. The size proxies with the total natural logarithm of assets owned shows the company's ability to maintain business continuity (Tandungan and Mertha, 2016). Large companies are considered to have better ability to manage the company and produce quality financial reports (Saifudin and Trisnawati, 2015).

Going-concern audit opinion is often issued for small companies because the auditor believes that financial difficulties in large companies can be more resolved than financial difficulties that occur in small companies. (Kristiandiastuti and Rasmini, 2016). H2: Company size negatively affect going concern audit opinion

c. A high current ratio provides an indication of good guarantees for short-term creditors in the sense that at any time the company has the ability to pay off its short-term financial obligations. However, high current ratio will negatively affect the ability to earn profit (earnings), because most of the capital does not spin or unemployment (Harjito and Martono, 2013). The smaller the value of the carrent ratio indicates the company is less liquid so it can be assumed that the company will have difficulty fulfilling the obligations to its creditors in this position the possibility of a large auditor will give a going concern audit opinion. H3: Current Ratio (CR) has a positive effect on going concern audit opinion.

d. States that clients usually perceive that auditors from public accountants are large and who have affiliation with international public accounting firms that have higher quality because they have characteristics that can be attributed to quality, such as training, recognition international as well as the existence of peer

review.

H4: Reputation of KAP has a positive effect on going concern audit opinion.

\section{RESEARCH METHODS}

Population and Sample In this research the sampling technique used is purposive sampling. Purposive sampling is a technique of determining samples with certain considerations (Sugiyono, 2016). In this study, the population studied is agricultural sector.

\subsection{Definition and Measurement of Variable Independent Variable}

In this study there are independent variables:

Debt to Equity Ratio (DER) is the ratio used to assess debt with equity. This ratio is useful to know the amount of funds provided by the borrower (creditor) with the owner of the company. This ratio serves to find out each rupiah own capital 
used for debt guarantees. The formula used to calculate Debt to Equity Ratio (DER) is as follows:

DER $=$

Source: Kasmir, 2015

The size of a client's firm is the size of a company measured by total assets. The greater the total assets of a company indicates that the size of the company is large, otherwise the smaller total assets of a company indicate that the size of the company is small. Client company size variable in this study is calculated using the following formula:

Ln $=$ Total Assets

Source : Tandungan dan Mertha, (2016).

Current ratio is a ratio to measure a firm's ability to pay short-term or debt that is due sooner when billed in its entirety. In other words, how much current assets are available to cover short-term liabilities or debts that mature soonThe current ratio can also be said as a form to measure the level of a company.

Current Ratio $=$

Source : Kasmir, 2015

KAP reputation shows the auditor's ability to be independent and conduct audits professionally. Public Accounting Firm (KAP) is classified into two namely KAP big four and KAP non big four. This variable is measured using the dummy variable, which is the number 1 given if the firm is audited by KAP big four and 0 if the company is audited by KAP non big four. This data is obtained based on the audited financial statements of the companies completed with independent auditor's report (Tandungan and Mertha, 2016).

\subsection{Dependent Variable}

Dependent variable in this research is going concern audit opinion given by auditor. A going concern audit opinion is an audit opinion issued by the auditor to ascertain whether the company can maintain its viability (SPAP, 2011). This variable is measured using dummy variables, where category 1 is given to companies receiving a going concern audit opinion while category 0 is given to companies that do not accept going concern audit opinion.

\subsection{Data Analysis Technique}

In this research, data analysis technique used is logistic data panel regression analysis with the help of sostware statistical data processing that is eviews 9.0. Logistic data logistic regression model can be written as follows (Ghozali, 2014): 


\begin{tabular}{ll}
\hline $\mathrm{GC}=\beta_{0}+\beta_{1} \mathrm{X}_{1}+\beta_{2} \mathrm{X}_{2}+\beta_{3} \mathrm{X}_{3}+\beta_{4} \mathrm{X}_{4}+\varepsilon$ \\
\hline $\mathrm{GC}$ & \\
\hline $\mathrm{GC}$ & $:$ Going Concern Audit \\
$\beta_{0}$ & $:$ Constants \\
$\beta_{1} \beta_{2} \beta_{3} \beta_{4}$ & $:$ Regression Coefficient \\
$\mathrm{X}_{1}$ & $:$ Debt to Equity Ratio \\
$\mathrm{X}_{2}$ & $:$ Return On Asset \\
$\mathrm{X}_{3}$ & $:$ Current Ratio \\
$\mathrm{X}_{4}$ & $:$ Reputation of KAP \\
$\varepsilon$ & $:$ Error
\end{tabular}

\section{RESULT AND DISCUSSION}

\subsection{Descriptive Statistic Analysis}

Table 1. Descriptive Statistic

\begin{tabular}{lccc}
\hline & DER & UP & CR \\
\hline Mean & 2.824625 & 15.30925 & 2.348000 \\
Maximum & 64.05000 & 17.30000 & 67.53000 \\
Minimum & 0.040000 & 11.60000 & 0.100000 \\
Std. Dev. & 8.296290 & 1.453322 & 7.569155 \\
\hline Observations & 80 & 80 & 80 \\
\hline \multicolumn{1}{c}{ Source : Processed Data Eviews 9 } & & &
\end{tabular}

Based on Table 1. above can be seen descriptive statistics showing the minimum, maximum, mean and standard deviation of each variable. Mean is the average of data by summing all the data and dividing it by counting data.

The largest mean value experienced by variable UP (company size) that is equal to 15.30925 while the variable CR (current ratio) has a mean value that is 2.348000 small. Maximum is the largest value of data. Maximum largest experienced by the CR variable is 67.5000 , while the UP variable has the smallest maximum of 17.30000. Minimum is the least value of data. The biggest minimum is experienced by UP variable that is 11.60000 , while DER variable has minimum that is equal to 0.040000 Std. Dev. (standard deviation) is the size of the dispension or dissemination of data. The largest standard deviation value experienced by the DER variable is 8.296290 , while the UP variable has the smallest standard deviation of 1.453322 .

For Public Accountant Firms (KAP) Reputation using Frequency Distribution, that is 80 data amount of research used is $36,3 \%$ or 29 amount of data using Big Four KAP and from 80 amount of research data used there are $63,8 \%$ or 51 amount data using KAP Non Big Four. 
For Going Concern Auditing Opinion there are $28.8 \%$ or 23 amount of data that get going concern audit opinion and $71.3 \%$ or 57 amount of data does not get going concern audit opinion. of 80 research data.

\subsection{Equations of Logistic Regression Model}

Table 2. Coefficient

\begin{tabular}{|l|r|}
\hline \multicolumn{1}{|c|}{ Variable } & \multicolumn{1}{c|}{ Coefficient } \\
\hline C & 21.17264 \\
\hline DER & 4.898103062 \\
\hline UP & 0.194931122 \\
\hline CR & 1.005337192 \\
\hline $\begin{array}{l}\text { Reputation of } \\
\text { KAP }\end{array}$ \\
\hline \multicolumn{2}{|c|}{ Source : Odd Ratio Data } \\
\hline
\end{tabular}

Table 2. above shows that the constant value ( $\beta 0) 21.17264$, coefficient of Debt to Equity Ratio ( $\beta 1)$ 4.898103062, Company Size coefficient ( $\beta 2)$ 0.194931122 , Current Ratio coefficient ( $\beta 3$ ) 1.005337192 and Reputation coefficient KAP ( $\beta 4$ ) 1.201955724. Based on the logistic regression test above, the equation is obtained as follows:

$\mathrm{Ln}-=21.17264+4.898103062 \mathrm{DER}+0.194931122 \mathrm{UP}+1.005337192 \mathrm{CR}+$ $1.201955724 \mathrm{KAP}+\varepsilon$

Constant value indicates that if Debt to Equity Ratio (DER), Company Size, Current Ratio (CR) and Reputation of KAP have value 0 (zero) then value of going concern audit opinion is 21.25997.

The coefficient of Debt to Equity Ratio (DER) is 4.898103062. This indicates that any $1 \%$ increase in Debt to Equity Ratio (DER) will be followed by a decrease in Going Concern Audit Opinion of 4.995332618 assuming other coefficients are considered fixed.

The coefficient value of Company Size is 0.194931122 . This indicates that any $1 \%$ increase in firm size will be followed by an increase in Going Concern Audit Opinion of 0.193912549 with the assumption that the other coefficients remain.

The coefficient value of Current Ratio is 1.005337192 . This indicates that any $1 \%$ increase in the Current Ratio will be followed by a decrease in Going Concern Audit Goals of 0.99760188.dengan other fixed coefficient assumptions.

The value of KAP reputation coefficient is 1.201955724 . This indicates that any $1 \%$ increase in KAP Reputation will be followed by a decrease in Going Concern Audit Goals of 0.99760188 with the assumption that other coefficients remain.

F-statistic value of 68.54865, while F Table with level $\alpha=5 \%$, df $1(\mathrm{k}-1)=4$ and df2 $(\mathrm{n}-\mathrm{k})=75$ in can $\mathrm{F}$ table value of 2.493696004 . Thus F-statistic (68.54865)> F Table $(2,493696004)$ and Prob value (F-statistic) $0.000000<0.05$ it can be concluded there is no difference between the model with the data so that the model is said fit and can be continued in this study. 
The value of McFadden R-squared is 0.714170 , meaning that the variation of the ups and downs of go concern audit opinion can be explained by DER, UP, CR, and KAP by $71 \%$. While the rest of $39 \%$ is explained by other variables not examined in this study.

\subsection{T Test (Z Statistic)}

Table 3. T Test Result

\begin{tabular}{crrrr}
\hline \hline Variable & Coefficient & Std. Error & Z-Statistic & Prob. \\
\hline \hline C & 21.17264 & 5.839653 & 3.625667 & 0.0003 \\
DER & 1.588848 & 0.501495 & 3.168223 & 0.0015 \\
UP & -1.635109 & 0.438299 & -3.730583 & 0.0002 \\
CR & 0.005323 & 0.172266 & 0.030900 & 0.9753 \\
KAP & 0.183950 & 1.114256 & 0.165088 & 0.8689 \\
\hline \hline
\end{tabular}

Source : Eviews 9

Based on table 3. it can be concluded that the t-test (Z-statistic) on logistic data panel regression analysis, as follows:

The value of (Z-statistic) Debt to Equity Ratio (DER) of 3.168223, while t Table with level $\alpha=5 \%$, df (n-k) $\Rightarrow$ t Table 1.992102154. Thus (Z-statistic) DER (3.168223)> t Table $(1,992102154)$ and Prob $0.00015<0,05$ it can be concluded that $\mathrm{H}_{1}$ is accepted and $\mathrm{H}_{0}$ is rejected, then Debt to Equity Ratio (DER) in this research positively affect the going concern audit opinion. These results indicate that the high or low level of corporate risk in paying off its long-term liabilities with its capital structure will affect the high or low get going concern audit opinion.

Value (Z-statistic) Company Size (UP) -3,730583, while t Table with level $\alpha=5 \%$, df $(\mathrm{n}-\mathrm{k}) \Rightarrow \mathrm{t}$ Table 1.992102154 . Thus (Z-statistic) UP $(-3.730583)>\mathrm{t}$ Table (1,992102154) and Prob $0.0002<0,05$ it can be concluded that $\mathrm{H}_{2}$ is accepted and $\mathrm{H}_{0}$ is rejected then Company Size (UP) negatively affects audit opinion going concern. The results of this study indicate that companies with large company size (UP), then the company can solve financial difficulties that it faces, so that the lower the company gets going-concern audit opinion.

Value (Z-Statistic) Current Ratio (CR) of 0.030900, while t table with level $\alpha=5 \%$, df (nk) = 75 obtained t table value of 1.992102154 and Prob value $0.9753>0.05$ then it can concluded that $\mathrm{H}_{0}$ is accepted and $\mathrm{H}_{3}$ is rejected then Current Ratio (CR) has no effect on going concern audit opinion. The results of this study indicate that the current ratio does not affect the going concern audit opinion because in this case the auditor not only see the ability of the company to meet the short term, but there are other factors such as conditions of financial difficulties indicated in the condition of losses experienced by the company so as to get an opinion audit going concern.

Value (Z-statistic) Public Accountant Firm (KAP) Reputation is 0.165088, while $\mathrm{t}$ table with level $\alpha=5 \%$, df $(\mathrm{n}-\mathrm{k})=75$ obtained $\mathrm{t}$ table value of 1.992102154. Accordingly, the KAP Reputation $(0.165088)<\mathrm{t}$ table $(1,992102154)$ and Prob value $0.8689>0.05$ then it can be concluded that $\mathrm{H}_{0}$ is 
accepted and $\mathrm{H}_{4}$ is rejected, then KAP reputation does not affect going-going audit opinion. The results of this study indicate that the Public Accountant Firm (KAP) reputation has no effect on going concern audit opinion because in carrying out its duties every auditor should be integrity, independent, objective and big four or non big four KAP is not a measure or benchmark in giving opinion audit opinion concern.

\section{CONCLUSIONS}

As for the conclusion, as follows:

1. Debt to equity ratio (DER) is proven empirically has a positive effect on going concern audit opinion on agricultural sector companies listed in Indonesia Stock Exchange period 2012-2016.

2. Company size is proven empirically negatively affect going concern audit opinion on agricultural sector companies listed in Indonesia Stock Exchange period 2012-2016.

3. Current ratio (CR) is proven empirically has no effect on going concern audit opinion on agricultural sector companies listed in Indonesia Stock Exchange period 2012-2016.

4. Public Accountant Firm (KAP) reputation proven empirically has no effect on going concern audit opinion on agricultural sector companies listed in Indonesia Stock Exchange period 2012-2016.

\section{REFERENCES}

Agoes, Sukrisno. (2012). Auditing Petunjuk Praktis Pemeriksaan Akuntan Oleh Akuntan Publik. Cetakan Ke Empat. Jakarta Selatan: Salemba Empat.

Elmawati, Dian dan Etna Nur Afri Yuyetta. (2014). Pengaruh Reputasi Kantor Akuntan (KAP), Audit Tenure, dan Disclosure Terhadap Penerimaan Opini Audit Going Concern. ISSN (Online): 2337-3806.

Handayani, Ni Wayan Surya dan Bhudiartha, I Ketut. (2015). Pengaruh Size, Profitabilitas, Loan To Deposit Ratio, dan Kecukupan Modal Terhadap Opini Audit Going Concern. E-Jurnal Akuntansi Universitas Udayana.

Harjito, Agus dan Martono. (2013). Manajemen Keuangan. Yogyakarta: Ekonisia.

Izzati, Sharlita Sara. (2014). Faktor-Faktor Yang Mempengaruhi Penerimaan Opini Audit Going Concern Pada Perusahaan Manufaktur Yang Terdaftar di Bursa Efek Indonesia. Jurnal Akuntansi, Keuangan dan Perbankan. 1

Ikatan Akuntansi Indonesia. (2015). Standar Akuntansi Keuangan. Jakarta: Salemba Empat.

Institut Akuntan Publik Indonesia. (2011). Standar Profesional Akuntan Publik. Jakarta: Salemba Empat.

Junaidi dan Nurdiono. (2016). Kualitas Audit Perspektif Opini Going Concern. Yogyakarta: CV Andi Offset. 
Kasmir. (2015). Analisis Laporan Keuangan. Jakarta: PT. RajaGrafindo Persada.

Krissindiastuti, Monica dan Ni Ketut Rasmini. (2016). Faktor-Faktor Yang Mempengaruhi Opini Audit Going Concern.

Mulyadi. (2014). Auditing 6 Edisi. Jakarta: Salemba Empat.

Purba, Marisi P. (2016). Asumsi Goung Concern Suatu Tinjauan Terhadap Dampak Krisis Keuangan Atas Opini Audit Dan Laporan Keuangan.2 Edisi. Yogyakarta: Ekuilibria.

Sitanggang. (2014). Manajemen Keuangan Perusahaan. 2 Edisi. Jakarta: Mitra Wacana Media.

Saifudin, Aris dan Trisnawati, Rina. (2015). Pengaruh Ukuran Perusahaan, Profitabilitas, Likuiditas, Solvabilitas, dan Pertumbuhan Perusahaan Terhadap Opini Audit Going Concern (Study Empirispada Perusahaan Manufaktur yang Terdaftar di Bursa Efek Indonesia Tahun 2011-2014). ISSN:2460-0784

Siregar, Baldric dan Rahman, Abdul. (2012). Kecendrungan Penerimaan opini Audit Going Concern: Studi Empiris Bursa Efek Indonesia.

Sugiyono. (2016). Metode Penelitian Kuantitatif, Kualitatif, dan R\&D. Bandung: Alfabeta.

Susanti, Yuli dan Bunandi. (2014). Analisa Faktor-Faktor Yang Mempengaruhi Penerimaan Opini Audit Going Concern. ISSN : 19076487.

Winarno, Wing Wahyu. (2015). Analisis Ekonometrika dan Statistika dengan Eviews. Yogyakarta: UPP STIM YKPN.

Wulandari, Soliyah. (2014). Analisis Faktor-Faktor Yang Mempengaruhi Auditor Dalam Memberikan Opini Audit Going Concern. E-Jurnal Akuntansi. ISSN: 2302-8556.

Tandiontong, Mathius. (2016). Kualitas Audit dan Pengukurannya. Bandung: Alfabeta

Tandungan, Debby dan Mertha, I Made. (2016). Pengaruh Komite Audit, Ukuran Perusahaan, Audit tenure Dan Reputasi KAP Terhadap Opini Audit Going Concern. ISSN: 2302-8556. 